\title{
The Myth of the Ancestral Homeland in Russian Neo-paganism
}

\author{
Alexey V. Osintsev and Olesya V. Kuznetsova* \\ Ural Federal University named after the B.N. Yeltsin \\ 51 Lenin, Ekaterinburg, 620083, Russia
}

Received 12.11.2014, received in revised form 18.01.2015, accepted 26.03.2015

The article discusses a number of concepts of ideologists in Russian neo-paganism of the Slavs ancestral homeland. The myth of the ancestral homeland is one of the major myths in Russian neo-paganism, regardless of the direction of the neo-pagan religious organization or group. It has the features of ethno-political myth, and it also serves as a source for a number of ideological, fundamentalist, and nationalist notions.

Keywords: religion, neo-paganism, myth of the ancestral homeland, modern mythology.

Research area: philosophy.

The appearance of numerous new religious organizations in the XX century, proclaiming the revival of ancient spiritual traditions, has its historical and cultural background. In Russia, fascination with the Russian antiquities appears in the XVIII and it amplifies in the XIX century. Moreover, it extends beyond the purely scientific research. Attempts to reconstruct some pagan rituals have been made by amateur enthusiasts. Perhaps the works of Russian authors of the late XIX and XX centuries can be traced back to the neo-pagan ideology. Still, active development of Russian neo-paganism occurs only during the «Perestroika» and the post-Soviet era. V.B. Yashin described a characteristic feature of the late Soviet and early post-Soviet years as «active participation of citizens in the political processes, which naturally stimulated the politicization of the religious sphere. Increased political activity then covered a significant part of new religious movements», and it left a unique imprint on the neo-paganism [15].

Processes of the twentieth century, stimulating the spread of neo-paganism in Europe, such as crisis of traditional forms of religiosity, market of religions, globalization issues, and environmental problems and so on, also influenced the Russian neo-paganism. However, in our opinion, intensive formation of Russian neopaganism was facilitated by the process of the late Soviet and post-Soviet reality, which triggered the collective identity crisis. Neo-paganism has become a way to satisfy social discontent among Russians. As pointed out by N. Smolina, discourse of identity crisis is intertwined with the discourse of collective trauma: «Such state is experienced as loss and confusion associated with the new reality. Trauma causes discomfort and feeling of

(C) Siberian Federal University. All rights reserved

* Corresponding author E-mail address: olesyakzn@yandex.ru, alexosv@ya.ru 
abandonment among most people, it intensifies fears (including the most irrational and least controlled of its manifestations - Fear of the elements or World War)» [8, p. 105]. According to Boris Dubin, it «makes mass consciousness switch to the nostalgic, compensatory projection of the idealized past» [4, p. 84]. In this sense, we can describe the Russian neo-paganism as a way of social adaptation in which a person is looking for ways to overcome the trauma. Trauma turns into a reflection on the transformation of the familiar world and collective identity.

In addition to religious and environmental issues, the majority of Russian neo-pagan groups include a political component. Plasticity of neopaganism ideas, absence of generally accepted dogma and continuous active construction of mythology allow it to incorporate various political traditions and concepts.

One of the peculiarities of Russian neopaganism is that it was formed in a secular state with atheistic worldview. Therefore, the controversy with the Christian vision of man and the world was not originally actualized, and it will take a significant place in the ideology of neo-paganism later (actively in the second half of the 90s.). There was initial disagreement with the authorities. Another specific feature of Russian neo-paganism was the fact that, unlike the Western European neo-paganism, it had no written texts of religious and mythological character, which could rely on in the construction of its mythology. In addition, science has limited data on the initial period of the history of the Eastern Slavs. Archaeology gives scant data on the history and culture of Eastern Slavs who lived on the territory of the future ancient Russia in the preliterate period. There are still many unresolved issues related to the ethnogenesis of Eastern Slavs. These circumstances and a special type of myth-making inherent in neo-paganism, lead to the possibility of designing their own mythology based on modern materials. They do not rely so much on the genuine and authentic historical texts, but rather on modern literary texts (novels and stories in the fantasy genre of the Slavs) and falsified texts (such as «Veles book», «Pravedy», «Slavic-Aryan Vedas» and others).

Common fundamental myths, uniting a variety of Russian neo-pagan groups are the following: the myth of lost golden age, including the description of the ancestral homeland of the Slavs; eschatological myth - as a way to explain the loss of «homeland» and the decline characteristic of modern time, as well as describing the contours of victory over evil and the establishment of native, fair and correct order. In the myth of Russian neo-pagans «ancestral homeland», we encounter a specific mythological chronotope and the idea of people inhabiting this space. «The past is interpreted through the principle of absolute tradition that is generally identified with the Original Tradition as an allencompassing womb of the most significant and best programs of life ... The future, paradoxically, turns out to be the «future-past», or a kind of retro-utopia as it is projected from a position of the involutional development principle as a truly progressive one» $[6$, p. 59].

V. Shnirelman believes that Russian neopagan mythology about the extensive ancestral homeland and the ancient habitat of the Slavs was formed mainly under the influence of such science fiction publications of the 1970s-1990s as V. I. Skurlatov (published under various pseudonyms) and V. I. Shcherbakov (who, in turn, actually revive V. M. Florinskiy's theories), as well as pseudo-scientific writings of V. A. Chivilikhin and V. N. Emelyanov. The myth of the Slavic «Aryan nature» stems from here. And all of these are aimed at building a rationale for Russia's rights to the territory of the former Russian Empire as genuinely ancestral [9, p. 14]. We find in classic Russian neo-paganism an idea 
of the wide dispersal of the Slavs in the world and their attitude towards the Slavic peoples.

Let us consider the most common version of the myth of the ancestral homeland of the Slavs. According to V. I. Skurlatov, «the ancient Slavs (in particular Rus and Croats) played an active role in the fate of Europe, Central and Southwest Asia since the beginning» [7]. He says that historians agree that the Cimmerian-Slav troops invaded Asia Minor and the Caucasus, he speaks about the Russian origin of the name of Hurrian King Rus I, as well as such names as Tiflis («Teplitsa»), Gordy and Gordion («city»), the ethnonym of one of Old Testament peoples called Roche (Ros) that terrified Semites [7]. He discusses it all in the prism of «historic dignity» (as measured by the scale of resettlement and ancient origin), which is strange and unusual for modern scientific research. Namely, that the Rus and other Slavic tribes have the same historical dignity as IndoIranians, Germans, Turks and other peoples and that their history has more than ten or fifteen centuries, and at least several thousand years [7].

$\mathrm{V}$. Shcherbakov, in an attempt to justify the greatness of the Slavs, also attributes vast expanse of Eurasia to the Slavic habitats and, moreover, mentions the spread of Slavic influence to other continents. He accomplishes this by ascribing nations to the Slavic world that do not belong to it, in particular, the Etruscans. The Etruscans, he says, on the one hand, is as a splinter of HittiteSlavic world, and on the other - connected with the origins of the Egyptian and Near Eastern civilizations, as well as the civilizations of Mesoamerica, and so on. [13]. The question of the «Russian-Etruscans» in a significant number of neo-pagans' ideas occupies an important place in theological issues and pseudoscientific research, no matter if the authors of such works consider themselves neo-pagans or not. Later, he identifies pre-Sumerian people of Mesopotamia with the «Rus» $=$ «Eastern and Titans». And to spite
Ukrainian authors who claim antiquity of the Ukrainian nation, which was formed by them, at least, to the emergence of the Kiev state, he said that Moscow was founded by northern «Vans» under the influence of the Rus long before Yuri Dolgoruky [12].

The problem of kinship or identity of the Slavs and Aryans is present in many Russian neo-paganism classics. V. A. Chivilikhin is called the first Soviet writer, who identified the Aryans with Slavs. The same idea was developed by V. N. Emelyanov, A. Ivanov (Skuratov) and others.

A. I. Asov (Barashkov), a well-known publisher and promoter of the falsified «Veles book», continued the tradition of the attributing the Slavs to the Atlantean civilization, pointing to the legend of the "Altyn kingdom» and its king Svyatogor and, recognizing «the story of Nestor,» as the history of medieval Russia, he reconstructs the history of Ancient Russia [1, p. 3, 17]. He claims that the Slavs had an impact on the ancient history of the Near East, as well as the Greek world, and argues that «Russia is a Eurasian country, both western and eastern « $[1$, p. 99-116, 141].

Extensive interest in the myth of the ancestral homeland and its relationship to ethnicity demonstrates some speculations in the field of linguistics. This was facilitated by V. I. Skurlatov, V. I. Shcherbakov and a number of other authors who created the myth of the great antiquity of the Slavic ethnic group, and were interested in the question of the existence of pre-Cyrillic Slavic scripture. As a result, a whole new trend that is not limited to the range of neopaganism (but very popular with a number of its followers, often regardless of affiliation to any particular group of neo-pagan) emerges, trying to present the Russian language as the oldest. One of the pioneers in this field (in amateur linguistics), is A. F. Shubin-Abramov, who since the late 
1970s spoke of «VseYaSvetnaya Gramota» («The Universal Alphabet»), but published it only in 1996. N.E. Beljakova's publication dedicated to it came out earlier - in 1994 [2]. A. F. ShubinAbramov insists on the existence of «preSlavonic alphabet», from whose comparison with other alphabets it should be noted that Greek and Hebrew were developed on the basis of a more ancient Slavic written language [11].

Another «popular academician», S. Danilov, continuing to work in a similar direction, focuses on the stages of the distortion of the true and original Russian language - «Slovene». In one of his video lectures, he refers to them as the stage of «language castration» and points out the artificial nature of the Ukrainian and Belarusian languages, which according to him were created as a result of the Bolshevik reform of the alphabet. Characterizing the same genuine Russian, S. Danilov goes further and says: «In the XXI century, finally, scientists have come to the conclusion that parts of the human brain, regardless of nationality, regardless of the white, yellow, red, black, gray race, communicate with each other in Russian» [3].

The concept of the existence of certain special single Russian language is present in the images of a single ancestral homeland. Unity of language appears: a) as a unity of the Slavic language, from which emerged all Slavic languages (which in the sense is close to understanding the relation of Slavic languages); b) as a «Russian language», from which came the East Slavic languages (e.g., Ukrainian, Belarusian) and various world languages, including non-Indo-European language families (e.g., Greek or Hebrew). The relation of languages is not important in itself, it is described as: a) the grounds for international cooperation; b) the justification of domination of the Slavs (Russian); c) the grounds for intervention in the affairs of other states and nations; g) understanding the universal kinship. In this regard, the nationalist motif is present everywhere (the superiority of the Russian language, the Russian people, and the Slavic peoples are proclaimed).

Conclusion. First of all, it must be emphasized that all findings should be taken with the side note that Russian neo-paganism from its origins could not be characterized as an ideologically unified movement. Nor can it be characterized this way now. It is significant that in most cases we do not see the unity in these issues even within organizations and groups of neo-paganism. It is postulated by their leaders in the manifestos and ideological doctrines, rather than actually exists in the individual minds of believers and in the information field, which makes up for their individual consciousness. Greater unity of views is more typical for radical nationalist groups. However, here we also see the history of splits, transformations, attempts to form new associations, starting from the oldest neo-pagan nationalist organization "Union of Weneds". In other words, genuine notions of the ordinary members of various neo-pagan groups and organizations can be presented as rhizome connecting pieces of the set of ideas expressed by leaders of various, often conflicting movements.

As we can see, the myth of the ancestral homeland of the Slavs in the Russian neopaganism is the ethno-political myth. Here we do not find the ontological perspective, characteristic of archaic myth. We agree with V. B. Yashin that "in Russian neo-paganism a striking example of the paradoxical combination of universal cosmopolitan and ultra-patriotic discourse is represented by the ancestral homeland of the Russian people" [14]. The ancestral homeland is widely localized (from Hyperborea to a tiny spot on the Earth), and all the nations somehow descended from Slavs or their history is associated with them. 
Another significant feature of the myth of the ancestral homeland is the motif of the loss and its belief that there are forces that prevent its revival, whether they are secret societies or entire nations seeking to enslave the Slavs (exaggerated anti-Semitic and racist ideas). In this part, the myth of the ancestral homeland shows the world emphatically dualistic, black and white. The boundaries of good and evil are distinct (though the reasoning of modern neo-pagan wizards concerning spiritual quest, keep coming back to the idea of good and evil, their reversibility and, ultimately indistinguishability). As pointed out by V. Shnirelman ethno-political "myth plays an instrumental role - it serves a very specific contemporary problem, whether it is territorial claims, demands for political autonomy or the desire to counteract the cultural leveling and preserve the cultural heritage " $[10$, p. 14]. The call for the restoration of the ancestral homeland is not only the restoration of borders, including the mythical ones. This is as a call for the restoration of "original", "clean", "undistorted" tradition; in this regard, we can talk about the manifestations of the fundamentalist features in the Russian neo-paganism. Restoring the ancestral homeland is a religious-political agenda (in varying degrees of expression) and in some cases bears the features of fundamentalism: "sacralization and literal understanding of the text, millenarianism, sharp dualism, there is no alternative representation, marginalization, "demonization" of Other" [5, p. 120]. In terms of international politics, it involves at least, strengthening the role of Russia and protection of Russian and Slavic everywhere in the world by various methods, including the most radical ones. In domestic policy, it often implies significant changes in social structure, when the religious leaders of the current neo-pagans must become rulers of the country and the higher clergy. Restoration as the return to the ancestral homeland and the language becomes one of the important tasks of Russian neo-paganism.

\section{References}

1. Asov A. I. Great Mysteries of Russia: history, ancestral homeland, ancestors, shrines. Moscow: AST, 2014.

2. Belyakov N. E. Vseyasvetnaya gramota. 1000 years of oblivion. Saint-Petersburg, 1994.

3. Danilov S. Video lecture at http://www.youtube.com/watch?v=RL6wYz95md0 (access date $09 / 21 / 2014)$

4. Dubin B. Time and People: mass perception of social change. Living in Russia at the turn of the century. Moscow, 2007.

5. Kuznetsova O.V., Smolin N.S. \& Mareninova V.V. (2014) Fundamentalism vs fundamentalism: scientific and ordinary notions. Historical, philosophical, political and legal sciences, cultural studies and art history. Theory and Practice, № 12-3 (50). 119-124.

6. Mikheeva I. B. (2014) Neopaganism as a local response to global challenges: theoretical and methodological aspects. Colloquium heptaplomeres, №1. 57-61.

7. Skurlatov V. I. Imprint of the luminous, Access: http://www.rulit.net/books/tajny-vekov-sborniktehnika-molodezhi-antologiya-tainstvennyh-sluchaev-read-210995-129.html (access date 08/23/2014).

8. Smolina N. S. Soviet/post-Soviet as an object of socio-philosophical analysis: problems of collective identity: PhD dissertation; Urals State University. Yekaterinburg: [b.i.], 2009.

9. Shnirelman V. Russian Slavic neo-paganism: Neo-paganism and nationalism in contemporary Russia. Moscow, BBI, 2012. 
10. Shnirelman V. (2000) Value of the past: ethnocentric historical myths, identity and ethnic policies. Reality of ethnic myths/ Moscow, 2000. 12-33.

11. Shubin-Abramov A. F. VseYaSvetnaya Gramota, Access: http://dm80.ru/lib/prayazik/ (date accessed 08/12/2014).

12. Sherbakov V. I. Mystery of Aquarius Age. Access: http://royallib.ru/book/shcherbakov_ vladimir/tayni_eri_vodoleya.html (date accessed 08/12/2014).

13. Sherbakov V. I. Troyan Trail. Access: http://www.kladina.narod.ru/sherbakov/sherbakov.htm (date accessed 12/08/2014).

14. Yashin V. B. Patriotic and cosmopolitan in the Russian neo-paganism (on the example of the motif of the lost ancestral home). Religions Russia: problems of social service and patriotic education. Nizhniy Novgorod, VPO "NGLU”, 2014. 79-89.

15. Yashin B. V. Russian neo-paganism in the context of religious and political extremism. Access: http://cults.expert/2014/05/russian-neopaganism-yashin/ (date accessed 06/09/2014)/

\title{
Миф о прародине в русском неоязычестве
}

\author{
А.В. Осинцев, О.В. Кузнецова \\ Уральский федеральный университет им. Б.Н. Ельцина \\ Россия, 620083, Екатеринбург, пр. Ленина, 51
}

В статье рассматривается ряд концепџий идеологов русского неоязычества о прародине славян. Миф о прародине является одним из основных мифов русского неоязычества независимо от направления неоязыческой религиозной организации, группь. Он несет в себе черты этнополитического мифа, а также является источником для ряда мировоззренческих, фундаменталистских, наџионалистических суждений.

Ключевые слова: религиоведение, неоязычество, миф о прародине, современная мифология.

Научная специальность: 09.00.00 - философские науки. 